\title{
Temporal overlaps of feral cats with prey and competitors in primary and human-altered habitats on Bohol Island, Philippines
}

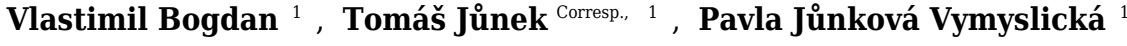 \\ ${ }^{1}$ Department of Ecology / Faculty of Environmental Sciences, Czech University of Life Sciences Prague, Prague, Czech Republic \\ Corresponding Author: Tomáš Jůnek \\ Email address: tom junek@yahoo.com
}

The vertebrate fauna of the Philippines, known for its diversity and high proportion of endemic species, comprises mainly small- to medium-sized forms with a few large exceptions. As with other tropical ecosystems, the major threats to wildlife are habitat loss, hunting and invasive species, of which the feral cat (Felis catus) is considered the most damaging. Our camera-trapping study focused on a terrestrial vertebrate species inventory on Bohol Island and tempo-spatial co-occurrences of feral cats with their prey and competitors. The survey took place in the Rajah Sikatuna Protected Landscape, and we examined primary rainforest, its border with agricultural land, and rural areas in the vicinity of villages. Altogether, over 2,885 trap days we captured 30 species of vertebrates - 10 mammals (including Sus philippensis), 19 birds and one reptile, Varanus cumingi. We trapped $81.8 \%$ of expected vertebrates. Based on the number of events, the most frequent native species was the barred rail (Gallirallus torquatus). The highest overlap in diel activity between cats and potential prey was recorded with rodents in rural areas $(\Delta=0.62)$; the lowest was in the same habitat with ground-dwelling birds $(\Delta=0.40)$. Cat activity was not recorded inside the rainforest; in other habitats their diel activity pattern differed. The cats' activity declined in daylight in the proximity of humans, while it peaked at the transition zone between rainforest and fields. Both rodents and ground-dwelling birds exhibited a shift in activity levels between sites where cats were present or absent. Rodents tend to become active by day in cat-free habitats. No cats' temporal response to co-occurrences of civets (Paradoxurus hermaphroditus and Viverra tangalunga) was found but cats in diel activity avoided domestic dogs (Canis lupus familiaris). Our first insight into the ecology of this invasive predator in the Philippines revealed an avoidance of homogeneous primary rainforest and a tendency to forage close to human settlements in heterogeneous habitats. A detailed further investigation of the composition of the cat's diet, as well as ranging pattern, is still needed. 
1 Title

2 Temporal overlaps of feral cats with prey and competitors in primary and human-altered

3 habitats on Bohol Island, Philippines

\section{List of Authors}

5 Vlastimil Bogdan ${ }^{1}$, Tomáš Jůnek ${ }^{1}$, Pavla Jůnková Vymyslická ${ }^{1}$

$6{ }^{1}$ Department of Ecology, Faculty of Environmental Sciences, Czech University of Life Sciences

7 Prague, Kamýcká 129, 16521 Prague 6-Suchdol, Czech Republic,

\section{Corresponding Author}

9 Tomáš Jůnek,

10 Lindnerova 448/8, 18000 Prague, Czech Republic

11 E-mail address: tom_junek@yahoo.com

12

13

14

15

16

17

18

19

20

21

22

23 


\section{Abstract}

27 The vertebrate fauna of the Philippines, known for its diversity and high proportion of endemic species, comprises mainly small- to medium-sized forms with a few large exceptions. As with other tropical ecosystems, the major threats to wildlife are habitat loss, hunting and invasive species, of which the feral cat (Felis catus) is considered the most damaging. Our cameratrapping study focused on a terrestrial vertebrate species inventory on Bohol Island and tempospatial co-occurrences of feral cats with their prey and competitors. The survey took place in the Rajah Sikatuna Protected Landscape, and we examined primary rainforest, its border with agricultural land, and rural areas in the vicinity of villages. Altogether, over 2,885 trap days we captured 30 species of vertebrates - 10 mammals (including Sus philippensis), 19 birds and one reptile, Varanus cumingi. We trapped $81.8 \%$ of expected vertebrates. Based on the number of

37 events, the most frequent native species was the barred rail (Gallirallus torquatus). The highest overlap in diel activity between cats and potential prey was recorded with rodents in rural areas $(\Delta=0.62)$; the lowest was in the same habitat with ground-dwelling birds $(\Delta=0.40)$. Cat activity was not recorded inside the rainforest; in other habitats their diel activity pattern differed. The cats' activity declined in daylight in the proximity of humans, while it peaked at the transition zone between rainforest and fields. Both rodents and ground-dwelling birds exhibited a shift in activity levels between sites where cats were present or absent. Rodents tend to become active by

44 day in cat-free habitats. No cats' temporal response to co-occurrences of civets (Paradoxurus hermaphroditus and Viverra tangalunga) was found but cats in diel activity avoided domestic dogs (Canis lupus familiaris). Our first insight into the ecology of this invasive predator in the 
47 Philippines revealed an avoidance of homogeneous primary rainforest and a tendency to forage

48 close to human settlements in heterogeneous habitats. A detailed further investigation of the

49 composition of the cat's diet, as well as ranging pattern, is still needed.

\section{Introduction}

The Philippine Archipelago is considered a global biodiversity hotspot, known for its

52

53

54 55

high proportion of endemic species (Ambal et al. 2012). The terrestrial vertebrate taxa, which primarily encompass small to medium sized species, inhabit more than 7100 islands. These species include at least 213 mammals (Heaney et al. 2010), 674 birds (Lapage 2015), 270 reptiles and 111 amphibians (BREO 2015).

Similar to other oceanic islands, the predominantly small fauna of the Philippines suffers from the presence of competing invasive species, such as Rattus spp., and the feral cat (Felis catus). The cat is listed as the most widespread and probably most damaging of the four carnivores included on the list of the 100 worst invasive species (Lowe et al. 2000). At least 175 vertebrates are threatened or have been driven to extinction by feral cats on at least 120 islands (Medina et al. 2011). Meta-analysis has revealed that the negative impact of feral cats is largest for insular endemic mammals, and is exacerbated by the presence of invasive cat prey species such as mice (Mus musculus) or rabbits (Oryctolagus cunuculus) (Nogales et al. 2013). The cat is widely kept as a pet by people throughout the Philippines and can be found foraging in every habitat (Duffy \& Capece 2012). Despite the general prevalence of cats in the Philippine landscape, there is a noticeable lack of knowledge regarding the cat's impact on the biodiversity of this archipelago.

Cats feed on a wide range of animals, from arthropods, reptiles and birds to mammals the size of a rabbit (Pearre, Maass \& Maass 1998). In Australia alone, with a variety of animals of 
70 similar size such as those found in the Philippines, 400 prey species consumed by cats have been

71 recorded (Doherty et al. 2015). In the Philippines, members of the orders Chiroptera and

72 Rodentia are the most numerous mammalian species (Heaney et al. 2010). A wide range of

73 terrestrial and arboreal rodents with body mass ranging from the 15-g Musseromys spp. to the

74 2.6-kg Phloeomys spp. risk predation by cats. Only adult individuals of Phloeomys and Hystrix

75 pumila (Heaney et al. 2010) exceed the potential prey dimensions. According to size and niche,

76 members of the Tupaiidea (treeshrews), Erinaceidae (moonrats) and Soricidae family (shrews)

77 should be listed as mammalian prey for cats. Similarly, the smallest Philippine primate, Tarsius

78 syrichta, which inhabits Bohol and other islands of the Mindanao faunal region, can be included

79 (MacKinnon \& MacKinnon 1980).

80 On Bohol Island $\left(3,269 \mathrm{~km}^{2}\right)$, as on the other Philippine islands, bats and rodents

81 dominate among local mammals. The small mammalian fauna consists of one insectivorous

82 species and nine species of rodents, including the introduced Mus musculus, Rattus rattus, Rattus

83 norvegicus, Rattus tanezumi and Rattus exulans (Heaney et al. 2010). The avifauna of Bohol

84 numbers 235 species, with Passeriformes forming the largest sub-group at 83 species. Bohol is

85 also home to 14 ground-dwelling bird species inhabiting the woody or bushy inland habitats

86 potentially affected by cats (Kennedy 2000).

87 Along with dogs (Canis lupus familiaris), possible competitors of cats on Bohol include

88 two mammalian carnivores, Asian palm civet (Paradoxurus hermaphroditus) and Malayan civet

89 (Viverra tangalunga) (Heaney et al. 2010) and two reptile species: yellow-headed water monitor

90 (Varanus cumingi) and reticulated python (Python reticulatus) (BREO 2015). To our knowledge,

91 no predation between cat and civets has been published. 
The timing of activity of mammalian predators is a well discussed topic (e.g. Palomares

93

94

\& Caro 1999; Tambling et al. 2015). Time-stamped records from camera traps allow for detailed insights into the time budget and temporal coexistence of animals across trophic guilds, seasons, etc. (Rowcliffe et al. 2014), and recent camera trapping studies have successfully examined overlaps in diel activity patterns (Ridout \& Linkie 2009), confirming significant activity overlap between carnivores and their preferred prey (Harmsen et al. 2009; Lucherini et al. 2009; Sweitzer \& Furnas 2016) and suggesting predator behavior to reduce foraging energy expenditure (Foster et al. 2013). In their role as mesopredators cats must optimize their use of time not only to encounter prey but also to cope with a sympatric superior predator (Brook, Johnson \& Ritchie 2012). The combination of partitioning of habitat, prey size and a 24-hour daily cycle is thought to be a complex mechanism allowing competing felids to coexist in different animal communities (Di Bitetti et al. 2010; Foster et al. 2013; Silmi, Anggara \& Dahlen 2013; Sunarto et al. 2015). For example, low overlap in activities has been found between marbled cat (Pardofelis marmorata) and clouded leopard (Neofelis nebulosa) in Thailand (Lynam et al. 2013). Wang \& Fisher (2012) also confirmed higher segregation of diel activities of cats with respect to dingoes during wet months. The particularly suppressive effect of an apex carnivore on invasive populations of cats is considered an important conservation issue (Brook, Johnson \& Ritchie 2012; Lazenby \& Dickman 2013; Doherty, Bengsen \& Davis 2015). We conducted a camera-trap survey on Bohol Island in an attempt to uncover tempo-spatial cooccurrences of terrestrial vertebrate species on regularly used trails and to confirm the presence of cats in the protected primary rainforest (Zone I), a transition zone along the border of the primary rainforest with the agricultural landscape (Zone II), and inside the rural landscape in the proximity of human settlements (Zone III). Our objectives were to: (1) create a general inventory 
115 of camera-trapped taxa; (2) model the species accumulation curve using previous knowledge of

116 the possible number of mammalian, avian and reptile species detectable by camera-traps; and (3)

117 compare the diel activity levels of cats with those of potential prey and competitors.

\section{Materials \& Methods}

119 Study site

120 Our study was conducted under research permit No. 2014-04, issued by DENR, Region

121 VII, Philippines, between July $2^{\text {nd }}$ and December $4^{\text {th }}, 2014$ in the surroundings of the town of

122 Bilar, Bohol Island, Philippines. The landscape consists of a mixture of distinctive flat rural areas

123 near human settlements, used as rice fields and plantations for various crops, steep karst hills

124 covered by brush and secondary forest, and primary rainforest in protected areas. The town of

125 Bilar lies between two conservation areas, the Rajah Sikatuna Protected Landscape (RSPL) and

126 the Loboc River Watershed Forest Reserve. RSPL is the second largest protected sanctuary on

127 Bohol, covering 11,034 ha of a mostly hilly limestone environment rich in characteristic

128 landforms such as ravines, sinkholes and caves. The altitude in RSPL varies between 300 and

$129826 \mathrm{~m}$ above sea level. The forest canopy is multi-layered, with trees reaching up to $20 \mathrm{~m}$ in

130 height. Members of the families Dipterocarpaceae, Moraceae and Melicacea dominate the

131 canopy. Certain regions of RSPL have been reforested with white teak (Gmelina arborea) and

132 Honduras mahogany (Swietenia macrophylla) (Barcelona et al. 2006). The average annual

133 precipitation reaches $1,600 \mathrm{~mm}$; the rainy season typically lasts from June to December, with an

134 increase in precipitation to $200 \mathrm{~mm}$ per month. The driest month is April when approximately 40

$135 \mathrm{~mm}$ of rain falls.

136 Sampling design 
We monitored three types of landscape typical of tropical regions and deployed cameras

138 in groups, one camera per location, at eight trapping sites (Fig. 1): Zone I - protected primary

139 rainforest including the Watershed Forest Reserve (site WS), interior of RSPL (site SP) and

140 abandoned farms in the early stages of succession into RSPL (site SF); Zone II - transition zone

141 between the primary rainforest of RSPL and rice fields close to the village of Bulak (site BU),

142 transition zone between RSPL and rice and corn fields close to Logarita Springs (site LS), and

143 transition zone between RSPL and the farms of the village Binantay (site BI); Zone III - mixture

144 of brush and degraded forest and plantations on the edge of the village of Subayon (site SU), and

145 at Bohol Habitat Conservation Center on the edge of the town of Bilar (site HB). Details on

146 camera traps' deployment and duration of sampling are shown in Table 1.

147 Sampling procedures

148 We used 41 weatherproof infrared digital camera traps - 29 units of Ltl Acorn 5210MC

149 (Shenzhen Ltl Acorn Electronics Co., Ltd.) and 12 units of SPYPOINT IR7 (SPYPOINT ${ }^{\mathrm{MD}}$, G.G.

150 Telecom). Prior to the study, we tested both types of cameras in a week-long trial which was

151 focused on the difference in detection rates for moving objects. No difference larger than $10 \%$

152 between numbers of independence events was found. Both types of cameras were also used in 153 every habitat to avoid a bias from site-specific detection rates. Cameras were set up to perform

154 the same delay between recordings - SPYPOINT to take two images with a delay of $10 \mathrm{~s}$

155 between consecutive triggering, and Ltl Acorns to take one picture followed by a $5 \mathrm{~s}$ video, with

156 a 5 s delay between triggering. Video sequences served as an additional tool for the identification 157 of species.

158 We placed all cameras opportunistically on the most frequented trails or their junctions

159 and, according to the expected size of target vertebrates, we fastened cameras with a belt onto the 
160 trunks of trees or bushes nearest to the trail, at a height of up to $0.5 \mathrm{~m}$, with a focal point

161 approximately $2 \mathrm{~m}$ from the lens. All cameras were active 24 hours a day; all records in infrared

162 mode were available only in a black-and-white version. No bait was used.

163 Identification of taxa

164 Two observers, VB and TJ, independently identified all species visually from images and

165 videos; the results were mutually crosschecked, and disagreeing or unidentifiable records were

166 excluded from the analysis. Based on available databases (Heaney et al. 2010; BREO 2015;

167 Lapage 2015), we made a list of terrestrial mammalian and avian ground-dwelling species

168 known or expected to occur on Bohol (Table 2). From reptiles, we included only the largest four-

169 legged taxon, the yellow-headed water monitor (Varanus cumingi). Members of the order

170 Chiroptera and the strictly arboreal Philippine colugo (Cynocephalus volans) were a priori

171 omitted. The conservation status of each species was assessed following IUCN (2015).

172 Due to the limited nature of the recordings, for the identification process and the

173 calculation of a species accumulation curve all taxa the size of a mouse (Mus musculus and also

174 the insectivorous Crocidura beatus) were pooled into the group called 'mice', and all species of

175 rats (Rattus spp. and Bullimus bagobus) into the group 'rats'. In addition, both known species of

176 squirrels (Exilisciurus concinnus and Sundasciurus philippinensis) were grouped into one taxon:

177 'squirrels'. In total, the list consisted of eight taxa of mammals, 13 birds and one reptile. For

178 purposes of overlap analyses between cats and their competitors and prey, we pooled both native

179 carnivore species into a group called 'civets' and put mice, rats and squirrels into the group

180 'rodents'. Ground-dwelling species of birds were the second analyzed group of prey; dogs were

181 accordingly examined as competitors.

182 Data analysis 

consecutive images of an individual exceeded $10 \mathrm{~min}$. The same individual could theoretically trigger more than one camera within $10 \mathrm{~min}$. For each species and Zone, in Table 2 we reported

186

187

occurrences of species at cameras represented by events (Lazenby \& Dickman 2013).

We used a species accumulation curve based on the cumulative number of cameratrapping days, computed in EstimateS Version 9.1.0 (Colwell 2013), to find out if our survey lasted a sufficient number of days to capture the 22 expected terrestrial vertebrate species (including three pooled groups) known from Bohol. We followed Tobler et al. (2008) and calculated well-performing estimators of species richness: the non-parametric abundance-based estimator ACE, and the non-parametric incidence-based estimators ICE and Jackknife 1. An abundance-based rarefaction approach with 95\% confidence intervals and 1,000 random iterations of sample order was used.

The pair-wise temporal overlap of selected activity patterns was analyzed using the $\mathrm{R}$ statistical environment package 'overlap' (Meredith \& Ridout 2014). Following Ridout and Linkie (2009), we applied kernel density estimation on circular data pooled within all study sites. Density of activity (y-axis) uses a von Mises kernel, corresponding to a circular distribution, and is based on recorded time of each event on 24-hour x-axis. The coefficient of overlap $(\Delta)$ was calculated with a smoothing parameter of 1.0. We used a smoothed bootstrap of 10,000 resamples to determine standard errors and $95 \%$ confidence intervals. We only analyzed combinations of pairs of species, which scored at least 30 events in the activity record (Ridout, pers. comm.) in a given environment. The number of events used for calculation of the activity pattern overlap for each analyzed group of animals and each location is shown in Table 3.

\section{Results}


206

207

208

209

210

211

212

213

214

215

216

21

218

219

220

221 222 but excluded from the analysis.

223

224

225

226

227

Species inventory wallow in the interior of RSPL.

During the whole survey period, lasting 155 days, we accumulated 2,885 trap days and 2,034 events. The combined capture rate across all sites was 73.1 events per 100 trap days. The list of all 30 animal taxa recorded is shown in Table 2.

The most frequent native species was the barred rail (Gallirallus torquatus), captured in 183 independence events. We did not record four expected bird species: Megapodius cumingii, Coturnix chinensis, Turnix sylvaticus and Gallinago megala. On the other hand, we confirmed the survival of the Philippine warty pig (Sus philippensis). Given its size, it was probably a male individual that was captured, only once, on three images on August $9^{\text {th }}(6: 35 \mathrm{pm})$ in a mud

We found that feral cats most often occurred in the Zone II and III, and were absent inside the primary forest. A similar trend was found for ground-dwelling birds. Most rats and other small mammals were recorded in the transition Zone II between the RSPL forest and agricultural land. Along with feral cats and domestic dogs, we also recorded all three mediumsized mammals occurring on Bohol - the common palm civet (59 events), Malay civet (16 events) and long-tailed macaque (Macaca fascicularis) (7 events). Humans were also captured

Within all eight sampling sites, we captured 18 of 22 expected target taxa, which corresponds to a success rate of $81.8 \%$ of the species inventory $(100 \%$ of mammals and reptiles, $69.2 \%$ of birds). We used these 18 taxa for calculating the species accumulation curve (Fig. 2).

26 The mean estimated species richness computed in EstimateS was 19.7 species (ACE $=19.6$, ICE $22=19.5$ and Jackknife $1=20.0)$. We recorded 15.89 species $(72.2 \%$ of expected species $)$ in 1,000 
228 trap days. The eight target species of mammals were captured in 1,723 trap days; similarly, nine

229 ground-dwelling birds were recorded within 1,435 trap days.

230 Temporal overlaps

231 We recorded cats only in transition Zone II and in the rural landscape close to human

232 settlements (Zone III). Diel activity patterns of cats differed among zones (Fig. 3). Cats showed

233 a decrease in late-afternoon activity near villages, whereas activity in the transition area peaked

234 right before noon. Generally, the activity of cats by daylight was higher in transition zones; in

235 Zone III cats were recorded mainly at night.

236 The highest overlap in activity patterns between cats and rodents (Table 4) was found in

237 the rural landscape of Zone III, and between cats and ground-dwelling birds in transition Zone II

238 (Fig. 4).

239 Both categories of potential prey showed shifts in temporal occurrence within sites, based

240 on the presence of cat (Fig. 5). As seen, the peaks of rodent activity decreased in the hours before

241 sunrise and increased after sunset, whereas the activity of ground-dwelling birds peaked about 4

242 hours sooner at sites where cats were not recorded.

243 Cats showed the second lowest overlap among all groups with dogs in Zone III (Table 4)

244 where dogs were dominant and active during the day. In Zone II these two animals appeared to

245 peak in their activity at different times: dogs were most active in the morning and late afternoon,

246 whereas cats peaked before noon (Fig. 4).

247 The overlap between the diel activity patterns of cats and both species of civets is shown

248 in Figure 6. Cats exhibited roughly consistent activity throughout a 24-hour period, with no

249 apparent shift caused by the nocturnal occurrence of sympatric civets.

\section{Discussion}


252 has been conducted in the Philippines, nor any camera-trap-based species inventory on Bohol.

253 With the exception of the Philippine pygmy squirrel, Exilisciurus concinnus, we were able to

254 capture and identify every non-volant mammalian species recorded as occurring on Bohol larger

255 than a mouse, including an individual of Sus philippensis, which is considered to be close to

256 extinction (Oliver 1993), even by local people. Camera traps captured $81.8 \%$ of known ground-

257 dwelling mammalian, avian, and reptilian species, similar to the $86 \%$ captured in the Amazon

258 rain forest (Tobler et al. 2008) or $89 \%$ in the lowland rainforest of Borneo (Bernard et al. 2013);

259 both those camera-trapping studies were restricted to mammals. In addition, the initially steep

260 shape of our general species accumulation curve corresponds with studies conducted in tropical

261 ecosystems and confirms the robustness of the approach. Similarly to Rovero et al. (2014), we

262 captured the majority of selected species in 1,000 trap days, considered a reliable threshold

263 enabling the detection of rare species (O’Brien 2011).

264

The absence of cats in the interior of primary rainforest seems not to be driven by

265 distance from the nearest human settlements, given that all three monitored sites were up to

266 approximately $3 \mathrm{~km}$ from houses. We suggest that the absence of preferred features and habitats

267 in the rain forest may have resulted in camera traps failing to capture cats. Cats typically use a

268 mixture of vegetation cover at ground level which provides both cover and open space for

269 observing their prey; such habitat may increase hunting success (Doherty, Bengsen \& Davis

270 2015). The habitat heterogeneity hypothesis by Tews et al. (2004) predicts that heterogeneous

271 habitats offer a greater diversity and density of potential prey than homogeneous ones, which

272 could be conceivable for cats. Linear features in space (e.g. tree lines, roads and other corridors)

273 are generally considered to maximize cat's detectability (Crooks 2002; Bengsen, Butler \& 
274 Masters 2012). We would expect to record cats in primary forest mostly on trails (Trolle \& Kéry

275 2005; Harmsen et al. 2010; Anile et al. 2014) but they could disperse into the undergrowth on

276 paths that are undetected.

277 The presence of competing, potentially dangerous predators in primary forest is unlikely

278 to explain the absence of cats. Dogs and both species of civets were equally present in all three

279 zones. The common palm civet and Malay civet are omnivorous with a distinctive nocturnal

280 activity pattern (Jennings et al. 2009) but they forage in the habitat of cats, and given their size

281 we consider them to be competitors of cats. Nonetheless, cats do not show any temporal

282 avoidance, indicating no interspecies competition, which has evolved during almost a 500-year

283 co-existence (Jubair 1999). For a more comprehensive view of possible niche partitioning, as

284 found for example between felids on Sumatra (Sunarto et al. 2015), a camera-trapping study

285 should be conducted on Negros, where the Visayan leopard cat (Prionailurus bengalensis ssp.

286 rabori) occurs as a regional direct competitor (IUCN 2015).

287 Our results (Tables 2 and 3) show that species richness and availability of both prey

288 categories (rodents and birds) was higher, nearly by orders of magnitude, in both human-altered

289 zones than in primary rainforest. We attribute this to the variety of vertebrate and invertebrate

290 prey, which is more abundant in heterogeneous landscapes. In addition, as suggested by Lozano

291 et al. (2003), feral cats use a wide range of habitat components to meet their different activity

292 requirements (e.g. hunting, resting), and this landscape offers a mixture of agricultural features

293 with secondary growth, infrastructure and potential human subsidies (Ferreira et al. 2011). Our

294 data clearly support such a tendency to forage relatively close to human settlements, however we

295 were not able to determine from our records whether a photographed animal was feral or

296 domestic. 
Although the diel activity pattern of cats was roughly consistent over 24-h periods (Fig.

298

299

300

301

302

303

304

305

306

307

308

309

310

311

312

313

314

315

316

317

318

319

6), a detailed analysis of zones revealed a decline in diurnal activity in the vicinity of villages, in contrast to an apparent activity peak before noon in Zone II (Fig. 3). Both Zones II and III offered more-or-less the same number of prey species (Table 2). Compared with Zone II, we hypothesize that more uniform diurnal activity of relatively abundant dogs dissuaded cats from daytime foraging in Zone III (Fig. 4). Also subsidies provided by humans in villages could influence cats to remain inactive in shelters and forage at night. We did not detect any sign of cats being spatially excluded by dogs, but our results support findings that cats optimize their timing of hunting behavior to when dogs are less active, hence avoiding potentially dangerous encounters (Brook, Johnson \& Ritchie 2012; Wang \& Fisher 2012). Cats were more diurnal in Zone II. This could be explained by the same factor, because the zone-specific relative abundance index of dogs was two times lower than the index of cats than in Zone III (Table 3). So cats could respond both to lower disturbance from dogs and to higher diurnal availability of rodents in Zone II (Fig. 4). Other prey not detected by cameras such as insects or lizards might also be present (Bonnaud et al. 2011).

Prey species showed shifts in diel activity patterns between sites where cats were, or were not, present (Fig. 5). When cats were absent, rodents tended to forage visibly by day, while the activity of ground-dwelling birds peaked about 4 hours later. It is difficult to interpret the shift in bird activity; data from sites without cats were considered too scarce to perform a reliable analysis. Rodents shift their activities to become nocturnal if cats are present and more diurnal (Doherty et al. 2015). This raised the question of whether almost 500 years of cat presence in the Philippines has driven adaptive mechanisms of prey and competitors to cope with a new predator or not. Our results suggest that this already happened, similarly to the 4000-year history of the 
320 dingo in Australia (Carthey \& Banks 2012). Nevertheless, we believe that further research is

321 needed, especially throughout all seasons.

322 Knowledge of feral cat diet is paradoxically the least researched in tropical habitats with

323 the richest terrestrial biodiversity (Doherty et al. 2015; Doherty, Bengsen \& Davis 2015). Our

324 findings reveal the first tempo-spatial co-occurrences between feral cats and their potential prey

325 in a typical mixture of Philippine landscapes. We suggest feral cats' temporal avoidance of dogs

326 as the apex predator. We confirm that camera traps are capable of capturing small-bodied fauna,

327 ground-dwelling birds and highly elusive species, such as Sus philippensis, as well. Endangered

328 Philippine fauna exposed to invasive species should rapidly become the target of a broad and

329 long-term camera-trapping inventory survey. For an in-depth knowledge of the dietary intake of

330 feral cats in the Philippines, DNA analysis of scat is recommended as a priority for researchers

331 (Nogales et al. 2013). In addition, collared and GPS-tracked cats would provide information

332 about habitat use and the size of home ranges. Finally, attention should be paid to the cultural

333 value of cats kept as pets within Philippine society, to inform eradication strategies.

\section{Acknowledgements}

335 We would like to acknowledge the following persons and organizations which made our

336 study possible: Mr. Isabelo R. Montejo, regional director, and Mr. Eusalem S. Quiwag from the

337 Department of Environment and Natural Resources (DENR), Region VII, Philippines; the staff

338 of Rajah Sikatuna PL; Ms. Cristy Burlace and staff from the Habitat Bohol; Dr. Petr Anděl from

339 the Czech University of Life Sciences Prague; Ms. Monika Drimlová for tireless field work; and

340 two anonymous reviewers for comments on this manuscript.

341 References

342 Ambal, R.G.R., Duya, M. V, Cruz, M.A., Coroza, O.G., Vergara, S.G., Silva, N. De \& 

Conservation. Journal of Threatened Taxa, 4, 2788-2796.

345 Anile, S., Ragni, B., Randi, E., Mattucci, F. \& Rovero, F. (2014) Wildcat population density on 346 the Etna volcano, Italy: A comparison of density estimation methods. Journal of Zoology, 293, 252-261.

Barcelona, J.F., Dolotina, N.E., Madroñero, G.S., Granert, W.G. \& Sopot, D.D. (2006) The ferns and fern allies of the karst forests of Bohol Island, Philippines. American Fern Journal, 120.

Bengsen, A.J., Butler, J.A. \& Masters, P. (2012) Applying home-range and landscape-use data to design effective feral-cat control programs. Wildlife Research, 39, 258-265.

Bernard, H., Ahmad, A.H., Brodie, J., Giordano, A.J., International, L. \& York, N. (2013) Camera-Trapping survey of mammals in and around Imbak Canyon Conservation Area in Sabah Malaysian Borneo. The Raffles Bulletin of Zoology, 61, 861-870.

Di Bitetti, M.S., De Angelo, C.D., Di Blanco, Y.E. \& Paviolo, A. (2010) Niche partitioning and species coexistence in a Neotropical felid assemblage. Acta Oecologica, 36, 403-412.

Bonnaud, E., Medina, F.M., Vidal, E., Nogales, M., Tershy, B., Zavaleta, E., Donlan, C.J., Keitt, 359 B., Le Corre, M. \& Horwath, S. V. (2011) The diet of feral cats on islands: A review and a

BREO. (2015) Biodiversity Research and Education Outreach—Philippines, Http://philbreo.lifedesks.org/ an apex predator and indirect consequences for mesopredator suppression. Journal of 
applied ecology, 49, 1278-1286.

366 Carthey, A.J.R. \& Banks, P.B. (2012) When does an alien become a native species? A vulnerable 367 native mammal recognizes and responds to its long-term alien predator. PLoS One, 7 , $368 \quad$ e31804.

369 Colwell, R.K. (2013) EstimateS: Statistical estimation of species richness and shared species 370 from samples. Version 9.1.0. User’s Guide and application.

371 Crooks, K.R. (2002) Relative sensitivities of mammalian carnivores to habitat fragmentation. 372 Conservation Biology, 16, 488-502.

373 Doherty, T.S., Bengsen, A.J. \& Davis, R.A. (2015) A critical review of habitat use by feral cats 374 and key directions for future research and management. Wildlife Research, 41, 435-446.

375 Doherty, T.S., Davis, R.A., Etten, E.J.B., Algar, D., Collier, N., Dickman, C.R., Edwards, G., 376 Masters, P., Palmer, R. \& Robinson, S. (2015) A continental-scale analysis of feral cat diet 377 in Australia. Journal of Biogeography, 42, 964-975.

378 Duffy, D.C. \& Capece, P. (2012) Biology and Impacts of Pacific Island Invasive Species. 7. The 379 Domestic Cat ( Felis catus ) 1. Pacific Science, 66, 173-212.

380 Ferreira, J.P., Leitão, I., Santos-Reis, M. \& Revilla, E. (2011) Human-related factors regulate the 381 spatial ecology of domestic cats in sensitive areas for conservation. PLoS ONE, 6, 1-10.

382 Foster, V.C., Sarmento, P., Sollmann, R., Tôrres, N., Jácomo, A.T.A., Negrões, N., Fonseca, C. \& Silveira, L. (2013) Jaguar and Puma Activity Patterns and Predator-Prey Interactions in 384 Four Brazilian Biomes. Biotropica, 45, 373-379.

385 Harmsen, B.J., Foster, R.J., Silver, S.C., Ostro, L.E.T. \& Doncaster, C.P. (2009) Spatial and temporal interactions of sympatric jaguars (Panthera onca) and pumas (Puma concolor) in a 
neotropical forest. Journal of mammalogy, 90, 612-620.

388

389

390

391

392

393

394

395

396

397

398

399

400

401

402

403

404

405

406

407

408

Harmsen, B.J., Foster, R.J., Silver, S., Ostro, L. \& Doncaster, C.P. (2010) Differential use of trails by forest mammals and the implications for camera-trap studies: A case study from Belize. Biotropica, 42, 126-133.

Heaney, L.R., Dolar, M.L., Balete, D.S., Esselstyn, J.A., Rickart, E.A. \& Sedlock, J.L. (2010) Synopsis of Philippine Mammals, Http://archive.fieldmuseum.org/philippine_mammals/

IUCN. (2015) The IUCN Red List of Threatened Species. Version 2015.1., http://www.iucnredlist.org

Jennings, A.P., Veron, G., Wilson, D.E. \& Mittermeier, R.A. (2009) Family Viverridae (civets, genets and oyans). Handbook of the mammals of the world, 1, 174-232.

Jubair, S. (1999) Bangsamoro, A Nation under Endless Tyranny. IQ Marin.

Kennedy, R. (2000) A Guide to the Birds of the Philippines. Oxford University Press.

Lapage, D. (2015) Avibase - The Word Bird Database, Http://avibase.bsc-eoc.org/

Lazenby, B.T. \& Dickman, C.R. (2013) Patterns of Detection and Capture Are Associated with Cohabiting Predators and Prey. PLoS ONE, 8.

Lowe, S., Browne, M., Boudjelas, S. \& De Poorter, M. (2000) 100 of the World's Worst Invasive Alien Species: A Selection from the Global Invasive Species Database. Invasive Species Specialist Group Auckland, New Zealand.

Lozano, J., Virgós, E., Malo, A.F., Huertas, D.L. \& Casanovas, J.G. (2003) Importance of scrubpastureland mosaics for wild-living cats occurrence in a Mediterranean area: implications for the conservation of the wildcat (Felis silvestris). Biodiversity \& Conservation, 12, 921- 
409 Lucherini, M., Reppucci, J.I., Walker, R.S., Villalba, M.L., Wurstten, A., Gallardo, G., Iriarte, A., 410 Villalobos, R., Perovic, P., Society, W.C., Paz, L. \& Paz, L. (2009) Activity pattern 411 segregation of carnivores in the high Andes. Journal of Mammalogy, 90, 1404-1409.

412 Lynam, A.J., Jenks, K.E., Tantipisanuh, N., Chutipong, W., Ngoprasert, D., Gale, G.A.,

413 Steinmetz, R., Sukmasuang, R., Bhumpakphan, N., Grassman, L.I., Cutter, P., Kitamura, S., 414 Reed, D.H., Baker, M.C., Mcshea, W., Songsasen, N. \& Leimgruber, P. (2013) Terrestrial 415 activity patterns of wild cats from camera-trapping. Raffles Bulletin of Zoology, 61, 407416415.

417 MacKinnon, J. \& MacKinnon, K. (1980) The behavior of wild spectral tarsiers. International $418 \quad$ Journal of Primatology, 1, 361-379.

419 Medina, F.M., Bonnaud, E., Vidal, E., Tershy, B.R., Zavaleta, E.S., Josh Donlan, C., Keitt, B.S., 420 Corre, M., Horwath, S. V \& Nogales, M. (2011) A global review of the impacts of invasive 421 cats on island endangered vertebrates. Global Change Biology, 17, n/a-n/a.

422 Meredith, M. \& Ridout, M.S. (2014) overlap: estimates of coefficients of overlapping for animal 423 activity patterns. R package version 0.2. 2 .

424 Nogales, M., Vidal, E., Medina, F.M., Bonnaud, E., Tershy, B.R. \& Campbell, K.J. (2013) Feral 425 Cats and Biodiversity Conservation: The Urgent Prioritization of Island Management. 426 BioScience, 63, 804-810.

427 O’Brien, T.G. (2011) Abundance, density and relative abundance: a conceptual framework. 428 Camera Traps in Animal Ecology pp. 71-96. Springer.

429 Oliver, W.L.R. (1993) Pigs, Peccaries, and Hippos Status Survey and Conservation Action Plan. $430 \quad$ IUCN, Gland, p.219. 
431 Palomares, F. \& Caro, T.M. (1999) Interspecific killing among mammalian carnivores. The 432 American Naturalist, 153, 492-508.

433 Pearre, S., Maass, R. \& Maass, R. (1998) Trends in the prey size-based trophic niches of feral 434 and House Cats Felis catus L. Mammal Review, 28, 125-139.

435 Ridout, M.S. \& Linkie, M. (2009) Estimating overlap of daily activity patterns from camera trap 436 data. Journal of Agricultural, Biological, and Environmental Statistics, 14, 322-337.

437 Rovero, F., Martin, E., Rosa, M., Ahumada, J.A. \& Spitale, D. (2014) Estimating Species 438 Richness and Modelling Habitat Preferences of Tropical Forest Mammals from Camera 439 Trap Data (ed D Russo). PLoS ONE, 9, e103300.

440 Rowcliffe, M.J., Kays, R., Kranstauber, B., Carbone, C. \& Jansen, P. a. (2014) Quantifying 441 levels of animal activity using camera-trap data. Methods in Ecology and Evolution, n/a-n/a.

442 Silmi, M., Anggara, S. \& Dahlen, B. (2013) Using leopard cats (Prionailurus bengalensis) as 443 biological pest control of rats in a palm oil plantation. Journal of Indonesia Natural History, 1.

445 Sunarto, S., Kelly, M.J., Parakkasi, K. \& Hutajulu, M.B. (2015) Cat coexistence in central 446 Sumatra: ecological characteristics, spatial and temporal overlap, and implications for 447 management. Journal of Zoology, 296, 104-115.

448 Sweitzer, R.A. \& Furnas, B.J. (2016) Data from camera surveys identifying co-occurrence and 449 occupancy linkages between fishers (Pekania pennanti), rodent prey, mesocarnivores, and 450 larger predators in mixed-conifer forests. Data in brief, 6, 783-792.

451 Tambling, C.J., Minnie, L., Meyer, J., Freeman, E.W., Santymire, R.M., Adendorff, J. \& Kerley, 452 G.I.H. (2015) Temporal shifts in activity of prey following large predator reintroductions. 
453 Behavioral Ecology and Sociobiology.

454 Tews, J., Brose, U., Grimm, V., Tielbörger, K., Wichmann, M.C., Schwager, M. \& Jeltsch, F. 455 (2004) Animal species diversity driven by habitat heterogeneity/diversity: the importance of $456 \quad$ keystone structures. Journal of biogeography, 31, 79-92.

457 Tobler, M.W., Carrillo-Percastegui, S.E., Leite Pitman, R., Mares, R. \& Powell, G. (2008) An 458 evaluation of camera traps for inventorying large- and medium-sized terrestrial rainforest 459 mammals. Animal Conservation, 11, 169-178.

460 Trolle, M. \& Kéry, M. (2005) Camera-trap study of ocelot and other secretive mammals in the 461 northern Pantanal. Mammalia, 69, 405-412.

462 Wang, Y. \& Fisher, D.O. (2012) Dingoes affect activity of feral cats, but do not exclude them 463 from the habitat of an endangered macropod. Wildlife Research, 39, 611-620. 


\section{Figure 1}

Schematized map of the study area in the municipality of Bilar

Figure 1. Schematized map of the study area in the municipality of Bilar, Bohol, Philippines. Circles highlight eight sites surveyed from July to December 2014. 


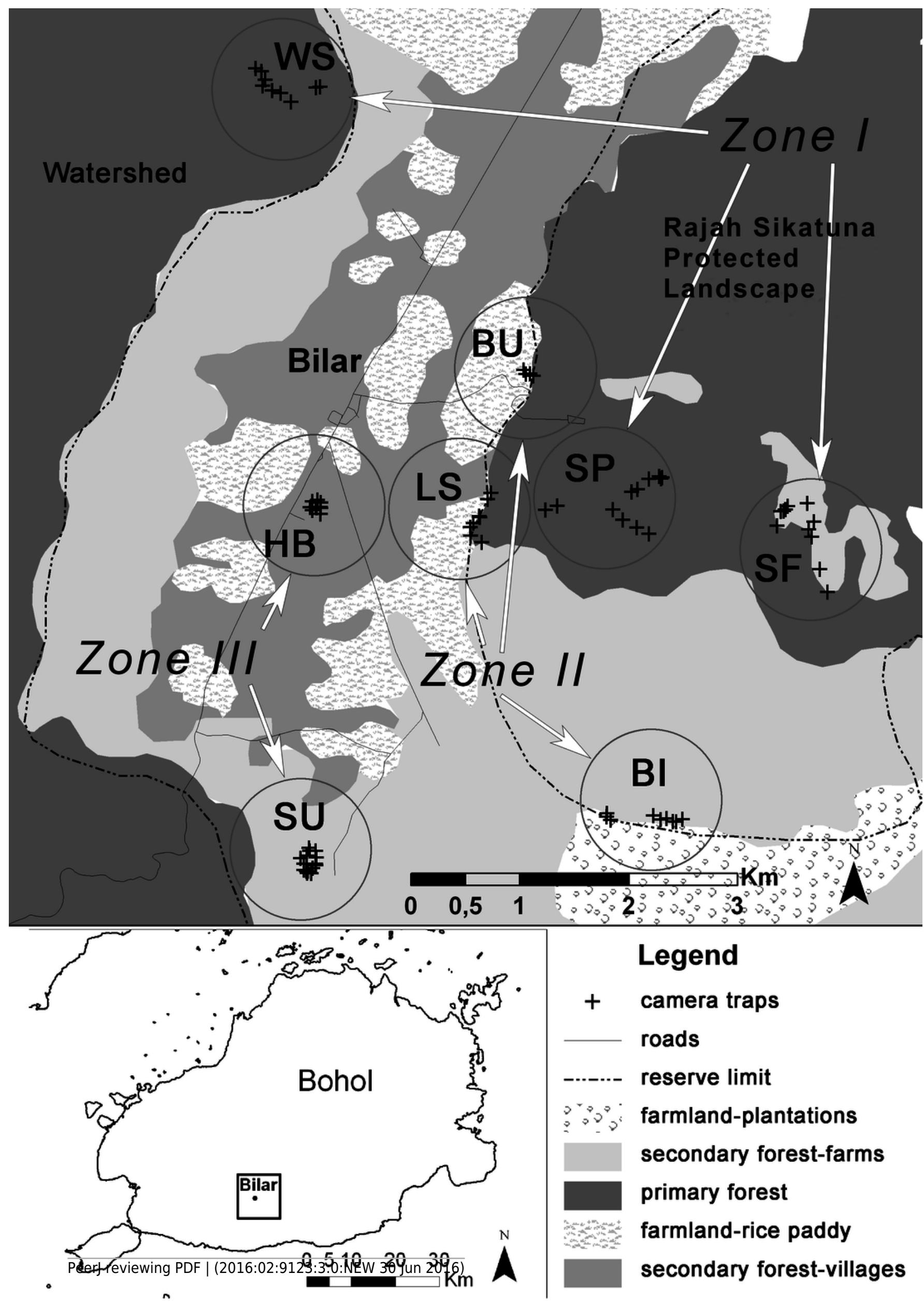


Figure 2

The species accumulation curves with $95 \%$ Cls for species captured in all categories of environment in 2,885 trap days

Figure 2. The species accumulation curves with $95 \% \mathrm{Cls}$ for species captured in all categories of environment in 2,885 trap days. The dashed-and-dotted line marks the known number of species, while the dotted lines represent species richness estimated by Jackknife 1 in EstimateS (Colwell 2013) .

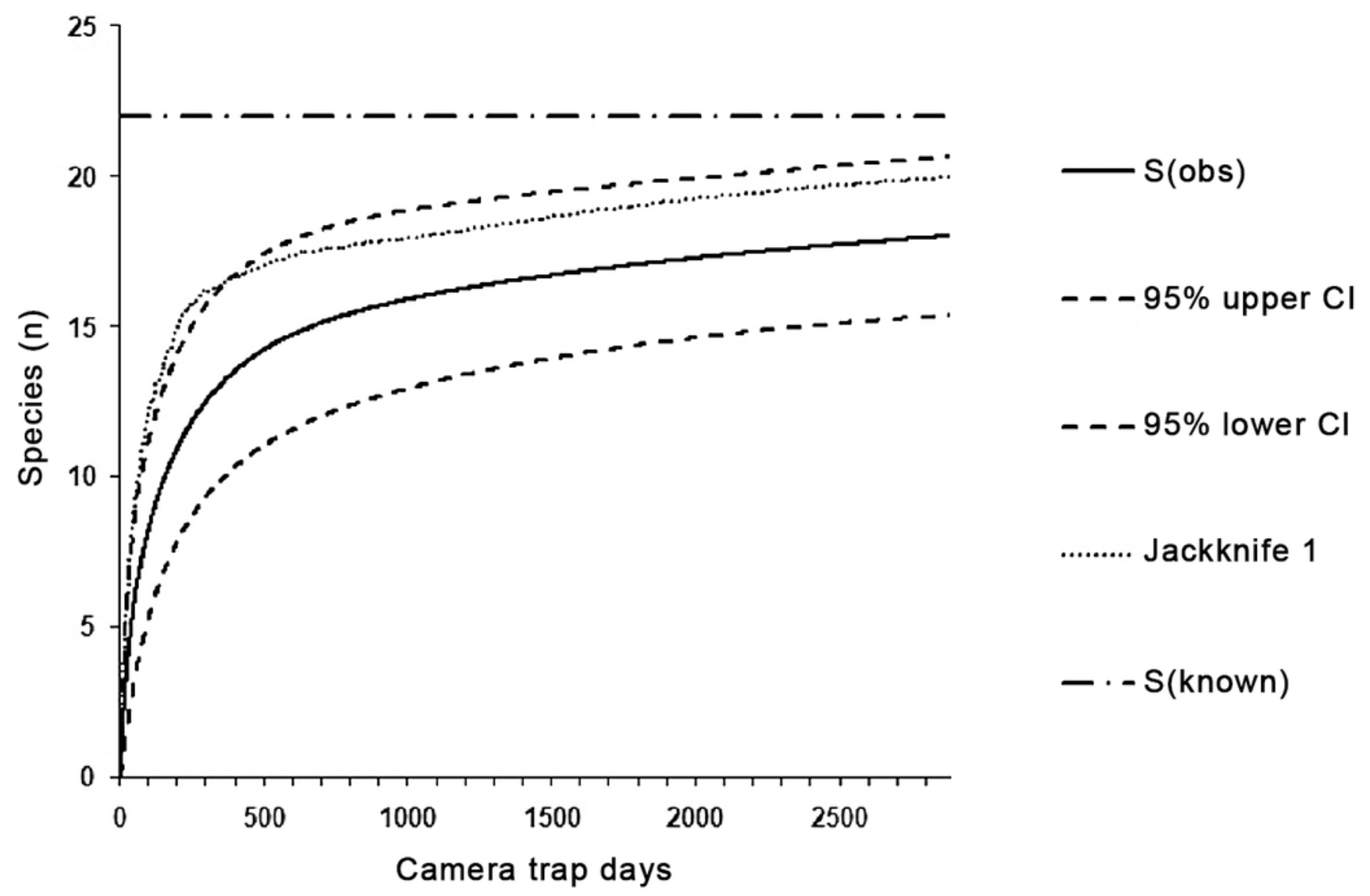


Figure 3

Overlap between diel activity patterns of cats in transition Zone II and rural Zone III

Figure 3. Overlap between diel activity patterns of cats in transition Zone II (dashed line) and rural Zone III. The number represents the coefficient of overlap $(\Delta)$, with standard error in parentheses.

cats zone II vs. zone III

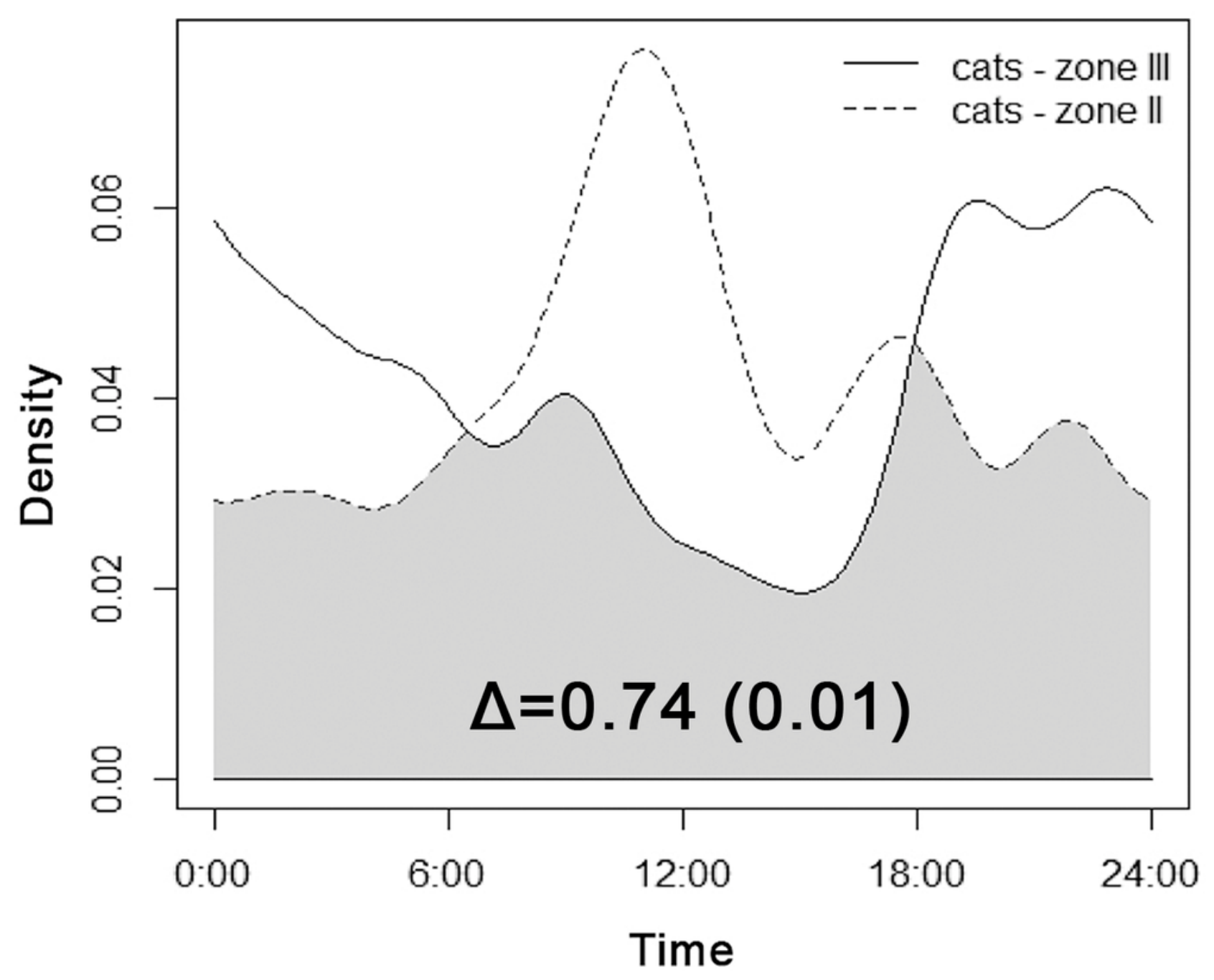




\section{Figure 4}

Overlap between the diel activity patterns of cats, rodents, ground-dwelling birds and dogs.

Figure 4. Overlap between the diel activity patterns of cats, rodents, ground-dwelling birds and dogs in transition Zone II (left) and rural Zone III. 

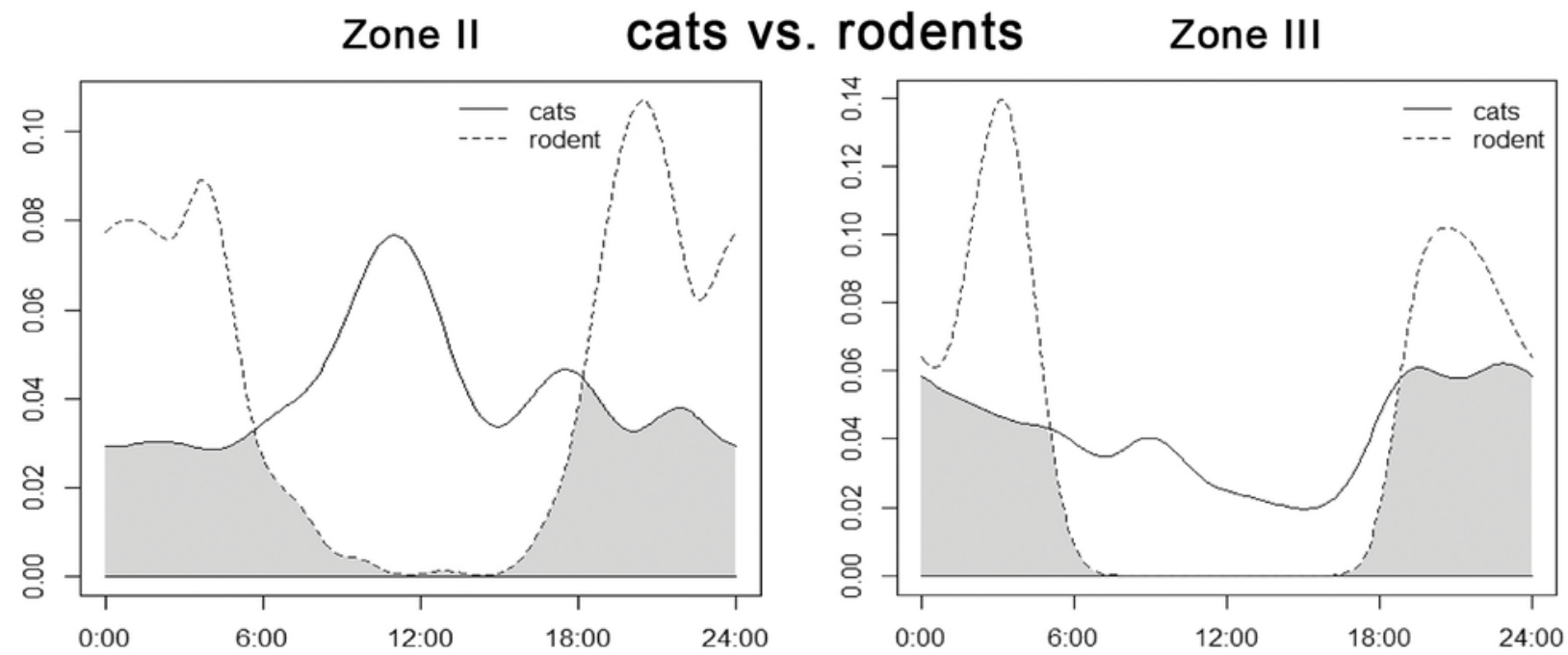

cats vs. ground-dwelling birds
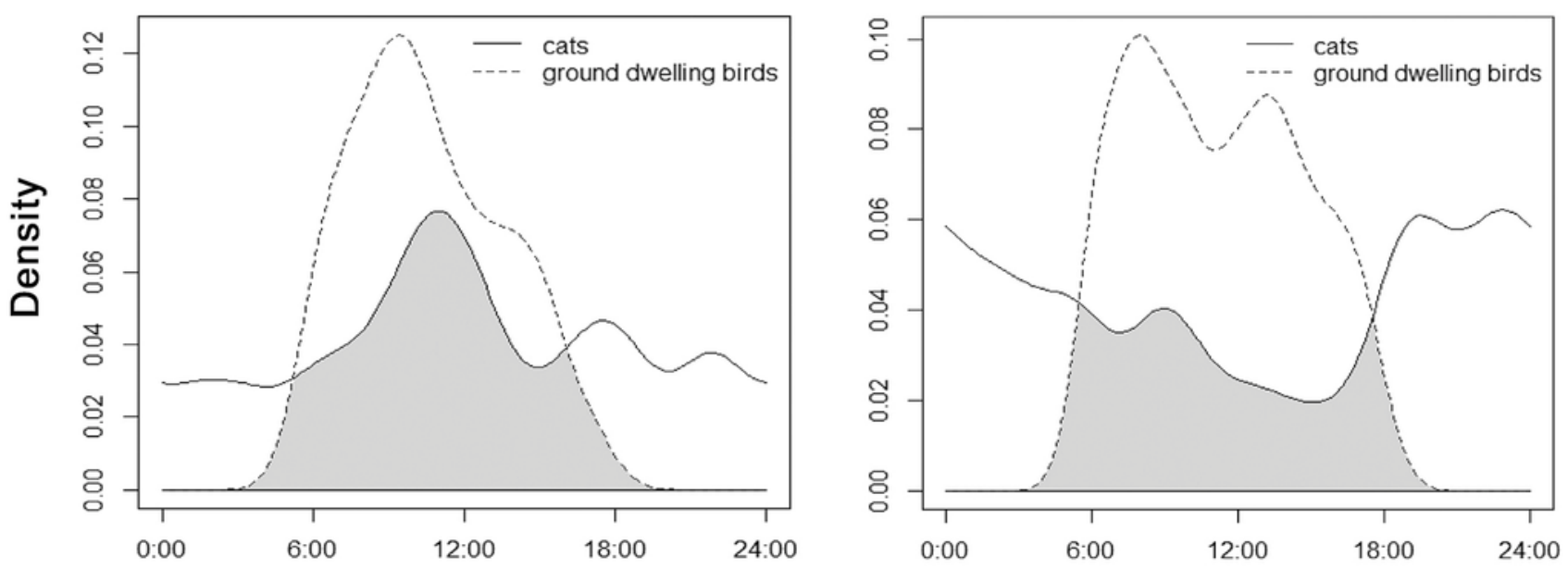

cats vs. dogs
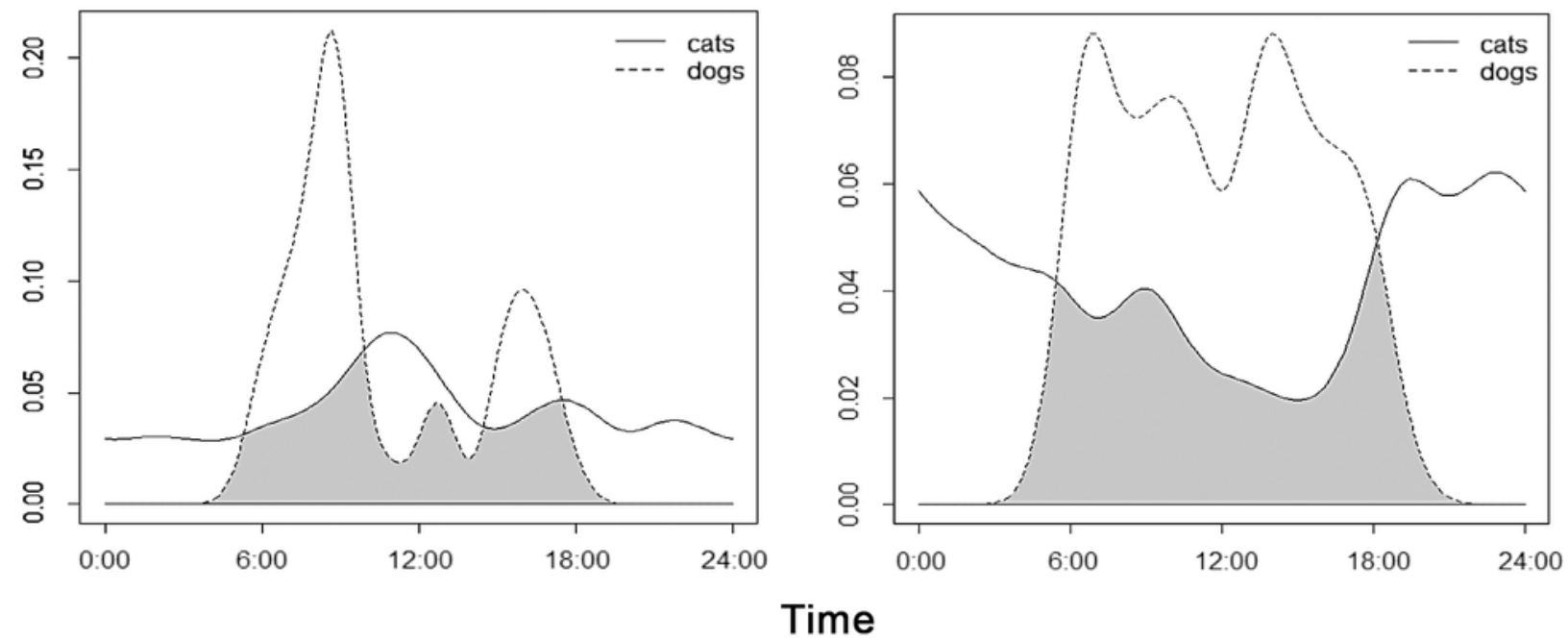
Figure 5

Overlap between the diel activity patterns of rodents and ground-dwelling birds at sites with and without the presence of cats

Figure 5. Overlap between the diel activity patterns of rodents (left) and ground-dwelling birds at sites with and without the presence of cats. The numbers represent coefficients of overlap $(\Delta)$ with standard errors in parentheses. Arrows indicate shifts in activity levels if cats are present.
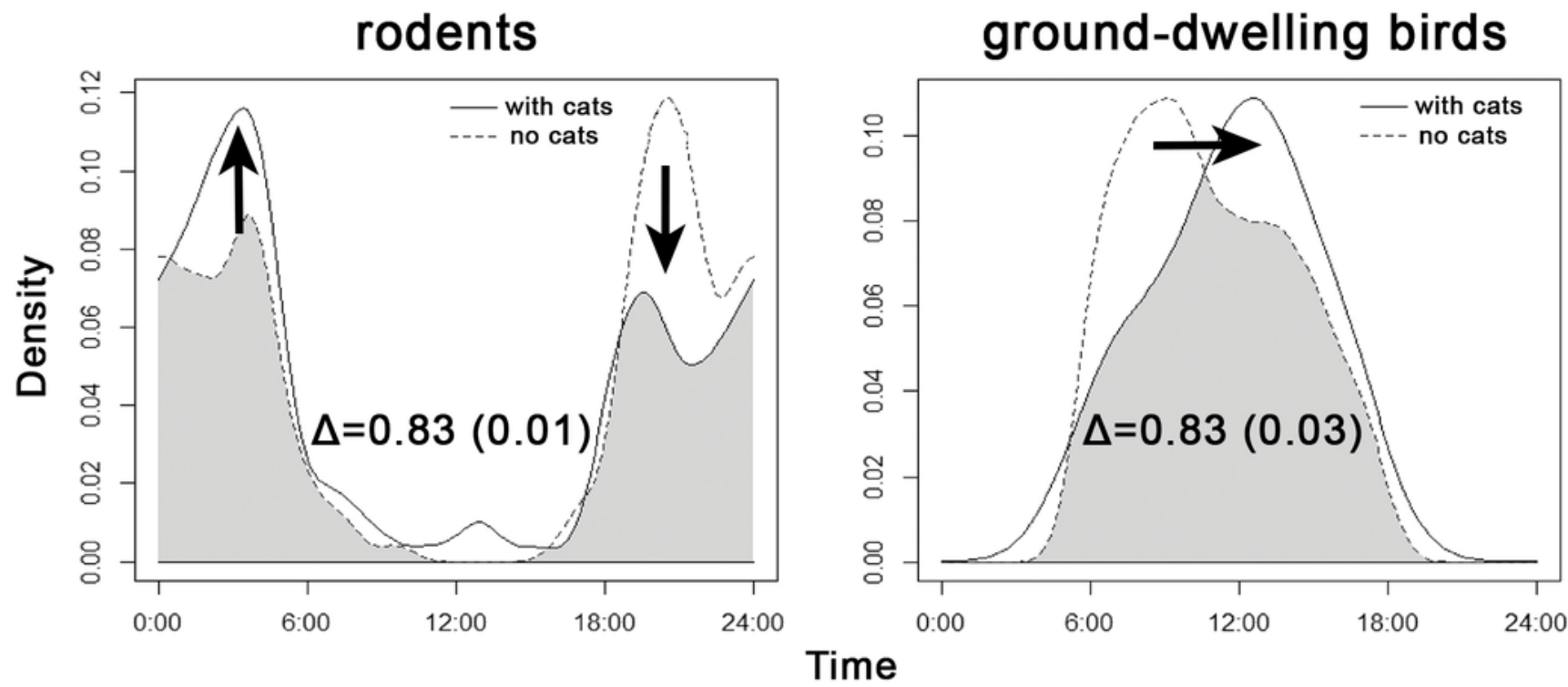
Figure 6

Overlap between the diel activity patterns of cats and both species of civets at all sites

Figure 6. Overlap between the diel activity patterns of cats and both species of civets at all sites of their occurrence.

cats vs. civets

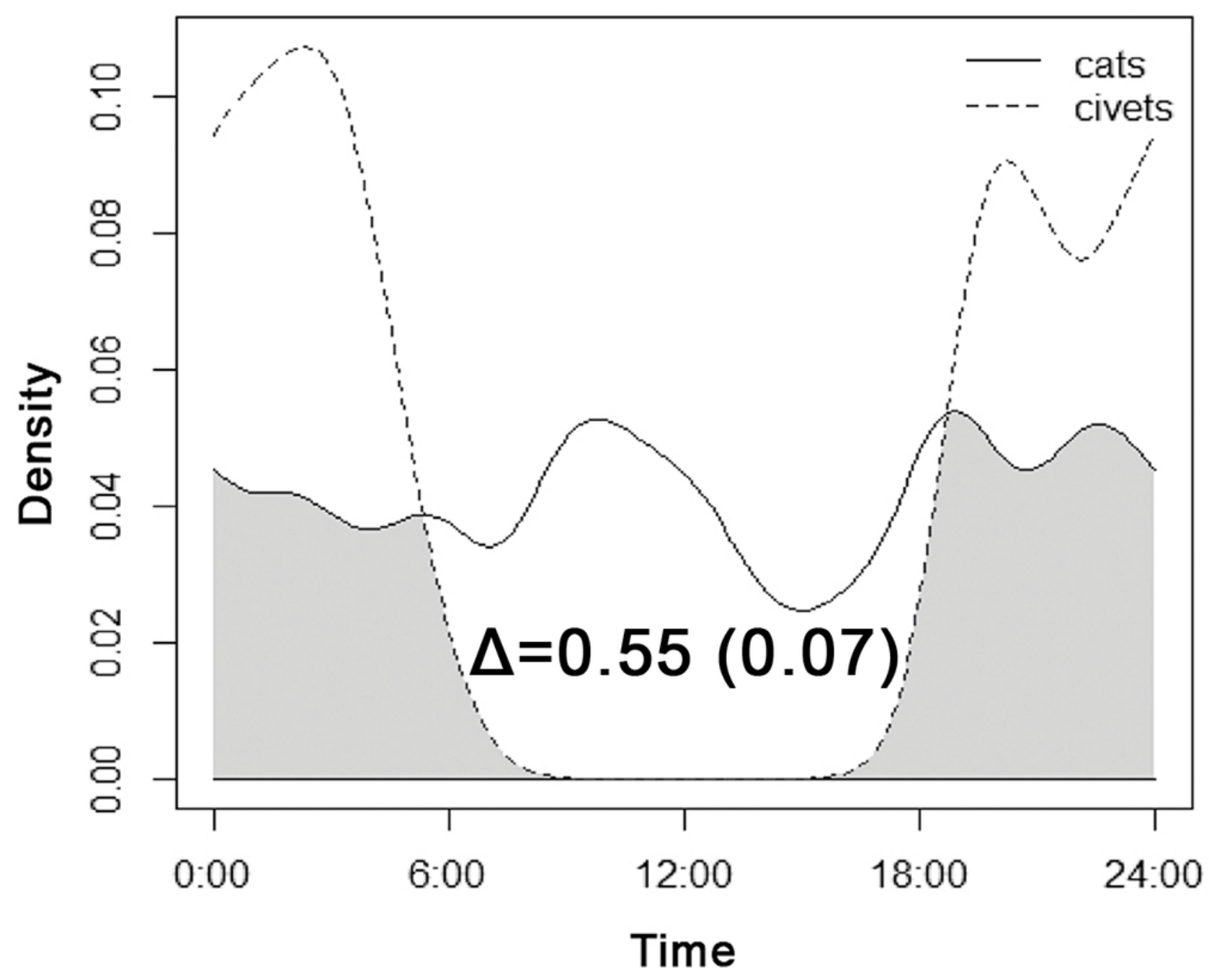




\section{Table $\mathbf{1}$ (on next page)}

Summary of the camera trap deployment

Table 1. Summary of the camera trap deployment in the area of the Rajah Sikatuna Protected Landscape, Bohol, Philippines. 
1 Table 1. Summary of the camera trap deployment in the area of the Rajah Sikatuna Protected

2 Landscape, Bohol, Philippines.

\begin{tabular}{cccccc}
\hline Zone & Site & Date & $\begin{array}{c}n \text { camera } \\
\text { traps }\end{array}$ & $\begin{array}{c}n \text { trap- } \\
\text { days }\end{array}$ & $\begin{array}{c}\text { Range of distances } \\
\text { between traps }(\mathrm{m})\end{array}$ \\
\hline I & SP & 12.7. -30.7.2014 & 12 & 204 & $60-514$ \\
I & SF & 30.7. - 14.8.2014 & 12 & 173 & $38-307$ \\
I & WS & 1.8. - 15.8.2014 & 9 & 125 & $37-265$ \\
II & BI & 2.8. - 4.12.2014 & 10 & 850 & $28-395$ \\
II & LS & $12.7 .-4.12 .2014$ & 7 & 536 & $48-174$ \\
II & BU & $2.8 .-4.12 .2014$ & 4 & 383 & $38-44$ \\
III & HB & $5.7 .-31.7 .2014$ & 10 & 224 & $25-236$ \\
III & SU & $2.7 .-31.7 .2014$ & 16 & 390 & $23-139$ \\
\hline
\end{tabular}

3

4

5 


\section{Table 2 (on next page)}

List of species recorded during a survey in the area of the Rajah Sikatuna Protected Landscape, Bohol, Philippines.

Table 2. List of species recorded during a survey in the area of the Rajah Sikatuna Protected Landscape, Bohol, Philippines. Species denoted with ' ${ }^{\prime}$ ' are those expected for the species accumulation curve. Values represent number of events of species recorded in each zone. 
1 Table 2. List of species recorded during a survey in the area of the Rajah Sikatuna Protected

2 Landscape, Bohol, Philippines. Species denoted with '*' are those expected for the species

3 accumulation curve. Values represent number of events of species recorded in each zone.

\begin{tabular}{|c|c|c|c|c|c|}
\hline Common name & Scientific name & Zone I & Zone II & Zone III & Site \\
\hline Philippine warty pig* & Sus philippensis & 1 & 0 & 0 & $\mathrm{SF}$ \\
\hline Common palm civet* & Paradoxurus hermaphroditus & 10 & 43 & 6 & $\mathrm{Su}, \mathrm{Bi}, \mathrm{LS}, \mathrm{Bu}, \mathrm{SP}, \mathrm{SF}, \mathrm{Ws}$ \\
\hline Malay civet* & Viverra tangalunga & 1 & 8 & 7 & $\mathrm{Ha}, \mathrm{Bi}, \mathrm{LS}, \mathrm{SP}$ \\
\hline Long-tailed macaque* & Macaca fascicularis & 3 & 4 & 0 & $\mathrm{LS}, \mathrm{Bu}, \mathrm{Ws}$ \\
\hline Philippine tarsier* & Tarsius syrichta & 0 & 1 & 2 & $\mathrm{Su}, \mathrm{LS}$ \\
\hline Philippine tree squirrel* & Sundasciurus philippinensis & 4 & 42 & 1 & $\mathrm{Su}, \mathrm{LS}, \mathrm{Bu}, \mathrm{SP}, \mathrm{SF}, \mathrm{Ws}$ \\
\hline Dog & Canis lupus familiaris & 14 & 39 & 91 & $\mathrm{Su}, \mathrm{Ha}, \mathrm{Bi}, \mathrm{LS}, \mathrm{Bu}, \mathrm{SP}$ \\
\hline Cat & Felis catus & 0 & 97 & 83 & $\mathrm{Su}, \mathrm{Ha}, \mathrm{Bi}, \mathrm{LS}$ \\
\hline Rat* & Rattus spp. & 32 & 242 & 47 & $\mathrm{Su}, \mathrm{Ha}, \mathrm{Bi}, \mathrm{LS}, \mathrm{Bu}, \mathrm{SP}, \mathrm{SF}, \mathrm{Ws}$ \\
\hline Mice* & Mus spp. & 5 & 217 & 5 & $\mathrm{Su}, \mathrm{Ha}, \mathrm{Bi}, \mathrm{LS}, \mathrm{Bu}, \mathrm{SP}, \mathrm{SF}, \mathrm{Ws}$ \\
\hline Yellow-headed water monitor* & Varanus cumingi & 1 & 6 & 5 & $\mathrm{Su}, \mathrm{LS}, \mathrm{SF}$ \\
\hline Hooded pitta* & Pitta sordida & 0 & 0 & 41 & $\mathrm{Ha}$ \\
\hline Red-bellied pitta* & Pitta erythrogaster & 0 & 42 & 0 & $\mathrm{Bi}, \mathrm{LS}$ \\
\hline Azure-breasted pitta* & Pitta steerii & 1 & 0 & 0 & Ws \\
\hline Striated wren-babbler* & Ptilocichla mindanensis & 1 & 9 & 0 & LS,Ws \\
\hline Red junglefowl* & Gallus gallus & 0 & 5 & 14 & $\mathrm{Su}, \mathrm{LS}, \mathrm{Bu}$ \\
\hline Barred rail* & Gallirallus torquatus & 0 & 4 & 179 & $\mathrm{Su}, \mathrm{Ha}, \mathrm{Bi}, \mathrm{LS}, \mathrm{Bu}$ \\
\hline Slaty-legged crake* & Rallina eurizonoides & 0 & 0 & 15 & $\mathrm{Su}, \mathrm{Ha}$ \\
\hline Ruddy-breasted crake* & Zapornia fusca & 0 & 2 & 1 & $\mathrm{Su}, \mathrm{Bu}$ \\
\hline Plain bush-hen* & Amaurornis olivacea & 0 & 0 & 10 & $\mathrm{Su}$ \\
\hline Black-faced coucal & Centropus melanops & 2 & 4 & 2 & $\mathrm{Su}, \mathrm{Bi}, \mathrm{LS}, \mathrm{Bu}, \mathrm{SF}, \mathrm{Ws}$ \\
\hline Philippine coucal & Centropus viridis & 0 & 2 & 3 & $\mathrm{Su}, \mathrm{Bu}$ \\
\hline Emerald dove & Chalcophaps indica & 7 & 7 & 16 & $\mathrm{Su}, \mathrm{Ha}, \mathrm{Bi}, \mathrm{LS}, \mathrm{Bu}, \mathrm{SF}, \mathrm{Ws}$ \\
\hline Philippine magpie-robin & Copsychus mindanensis & 0 & 3 & 1 & $\mathrm{Ha}, \mathrm{Bi}$ \\
\hline Mindanao bleeding-heart & Gallicolumba crinigera & 1 & 2 & 0 & LS,SP \\
\hline Hair-crested drongo & Dicrurus hottentottus & 1 & 0 & 0 & $\mathrm{SF}$ \\
\hline Besra & Accipiter virgatus & 0 & 1 & 1 & $\mathrm{Su}, \mathrm{Bi}$ \\
\hline Philippine hawk-owl & Ninox philippensis & 0 & 0 & 1 & $\mathrm{Ha}$ \\
\hline Yellow-breasted tailorbird & Orthotomus samarensis & 0 & 1 & 0 & $\mathrm{Bi}$ \\
\hline Domestic chicken & Gallus gallus domeaticus & 10 & 254 & 9 & $\mathrm{Su}, \mathrm{Bi}, \mathrm{LS}, \mathrm{Bu}, \mathrm{SP}, \mathrm{SF}$ \\
\hline
\end{tabular}




\section{Table 3 (on next page)}

Number of independent events used for calculation of activity pattern overlap for each analyzed group of animals and each location

Table 3. Number of events used for calculation of activity pattern overlap for each analyzed group of animals and each location in the area of the Rajah Sikatuna Protected Landscape, Bohol, Philippines. Values in parentheses show the zone-specific relative abundance index (events/total trap days in zone*100). Dashes denote unprocessed entries. 
1 Table 3. Number of events used for calculation of activity pattern overlap for each analyzed

2 group of animals and each location in the area of the Rajah Sikatuna Protected Landscape,

3 Bohol, Philippines. Values in parentheses show the zone-specific relative abundance index

4 (events/total trap days in zone*100). Dashes denote unprocessed entries.

\begin{tabular}{lllllcc}
\hline & Zone I & \multicolumn{1}{c}{ Zone II } & \multicolumn{1}{c}{ Zone III } & \multicolumn{1}{c}{ All sites } & no cats & with cats \\
\hline cats & $0(0)$ & $67(4.57)$ & $83(13.52)$ & $150(5.81)$ & - & - \\
dogs & $14(2.79)$ & $37(2.53)$ & $90(14.66)$ & $141(5.46)$ & - & - \\
rodents & $41(8.17)$ & $480(32.76)$ & $47(7.65)$ & $568(22.00)$ & $41(8.18)$ & $527(25.35)$ \\
ground-dwelling birds & $12(2.39)$ & $242(16.52)$ & $263(42.83)$ & $517(20.03)$ & $12(2.39)$ & $505(24.29)$ \\
civets & $11(2.19)$ & $16(1.09)$ & $13(2.12)$ & $40(1.39)$ & - & - \\
\hline
\end{tabular}

5 


\section{Table 4 (on next page)}

Activity pattern overlaps between cats, their potential prey and competitors in transition Zone II, rural Zone III and among all sites surveyed in the area of Bilar

Table 4. Activity pattern overlaps between cats, their potential prey (rodents and grounddwelling birds) and competitors (dogs and civets) in transition Zone II, rural Zone III and among all sites surveyed in the area of the Rajah Sikatuna Protected Landscape, Bohol, Philippines. 
1 Table 4. Activity pattern overlaps between cats, their potential prey (rodents and ground-

2 dwelling birds) and competitors (dogs and civets) in transition Zone II, rural Zone III and among

3 all sites surveyed in the area of the Rajah Sikatuna Protected Landscape, Bohol, Philippines.

\begin{tabular}{llcccc}
\hline & site & overlap $(\Delta)$ & $S E$ & $95 \% 1 C I$ & $95 \% \mathrm{u} C I$ \\
\hline cats vs. rodents & Zone II & 0.48 & 0.023 & 0.37 & 0.58 \\
& Zone III & 0.62 & 0.002 & 0.52 & 0.73 \\
cats vs. ground-dwelling birds & Zone II & 0.61 & 0.019 & 0.50 & 0.71 \\
& Zone III & 0.40 & 0.041 & 0.30 & 0.50 \\
cats vs. dogs & Zone II & 0.50 & 0.052 & 0.36 & 0.62 \\
& Zone III & 0.45 & 0.041 & 0.35 & 0.56 \\
cats vs. civets & All sites & 0.55 & 0.067 & 0.45 & 0.64 \\
\hline
\end{tabular}

4 